\title{
An Inherited Defect Affecting the Tricarboxylic Acid Cycle in a Patient with Congenital Lactic Acidosis
}

\author{
J. P. Blass, J. D. Schulman, D. S. Young, and E. Hom \\ From the Mental Retardation Center, University of California, Los Angeles \\ Medical School, Los Angeles, California 90024, and the National Institute of \\ Arthritis and Metabolic Diseases, the National Heart and Lung Institute, and \\ Clinical Laboratories of the National Institutes of Health, \\ Bethesda, Maryland 20014
}

A B S T R A C T Cultured skin fibroblasts from a $3 \mathrm{yr}$ old girl with severe, diffuse neurologic disease and persistant lactic acidosis, oxidized radioactive citrate, palmitate, and pyruvate at less than one-third the rate of control cells. Her fibroblasts oxidized isocitrate and glutamate at rates comparable with controls. In disrupted cells from this patient, the activity of aconitate hydratase appeared normal. The binding of citrate to aconitate hydratase and the activities of the NAD- and NADP-linked isocitrate dehydrogenases were also normal, while the activity of citrate synthase was slightly below control values. A significant defect was, however, apparent in the activity of the pyruvate dehydrogenase complex although not in the thiamine-dependent first enzyme of that complex. This patient appears to have a partial genetic defect affecting the tricarboxylic acid cycle.

\section{INTRODUCTION}

A number of workers have described children with persistent lactic acidosis and diffuse neurologic disease including mental retardation (1-15). Defects in gluconeogenetic enzymes have been demonstrated in several of these patients $(7,9,11,14)$. We have found a defect in oxidative metabolism in intact and disrupted fibroblasts cultured from the skin of a similar patient (16) and report the details of our studies below.

\section{METHODS}

Case report. The patient, a severely retarded $3 \mathrm{yr}$ old girl, was born of a consanguineous marriage in an inbred

Preliminary results were presented at the National Meeting of the American Federation for Clinical Research in 1970 (16).

Received for publication 15 November 1971 and in revised form 30 January 1972. population (Fig. 1). Her only sibling, a sister, died in infancy. The mother experienced several episodes of weakness and sweating during the first trimester, and the level of glucose in her blood on one such occasion was recorded as $50 \mathrm{mg} / 100 \mathrm{ml}$. Fetal movements were decreased during the third trimester. Birth weight was $2.6 \mathrm{~kg}$, and feeding was poor despite close parental attention. When the child was 7 months old, it was recognized that she was not developing motor skills normally but at this age deficits appeared mild. Doctors Martine Yarbro and Jaqueline Noonan first made the diagnosis of lactic acidosis at the University of Kentucky Medical Center when the child was 18 months old. Extensive studies of this patient at several medical centers have documented increasingly severe neurologic disease and are to be the subject of a separate clinical report.

On admission to the NIH, the patient had severe diffuse neurologic disease. Height and weight were normal. There were bilateral epicanthal folds, a slightly high-arched palate, and mild pectus excavatus. The head circumference (45 $\mathrm{cm}$ ) was in the microcephalic range. Marked strabismus and severe optic atrophy were present; the patient was probably blind. Muscular hypotonia accompanied hyperactive reflexes and scissoring. Her movements were poorly coordinated, but could not be classified into a known category of movement disorder. The eye movements seemed nystagmoid to some observers. Vocabulary was about 20 words. The child was not toilet trained. She appeared grossly mentally retarded and irritable and formal psychologic testing was not attempted. Sensation appeared intact to pinprick; sweating was normal.

The patient was maintained on a high-protein diet during the completion of the laboratory studies described below. Clinical and clinical laboratory studies were limited, since informed consent for a number of procedures including dietary variation and repeated sampling of physiological fluids was not obtained. Since discharge, further deterioration of the child's condition has reportedly occurred.

Clinical laboratory studies. Lactic and pyruvic acid levels in blood were persistently elevated (Fig. 2), despite therapy with thiamine hydrochloride (up to $600 \mathrm{mg}$ orally and $200 \mathrm{mg}$ parenterally, daily) or with nicotinamide (1.0 $\mathrm{g}$ /day orally). Citric acid levels (17) in the patient's blood 


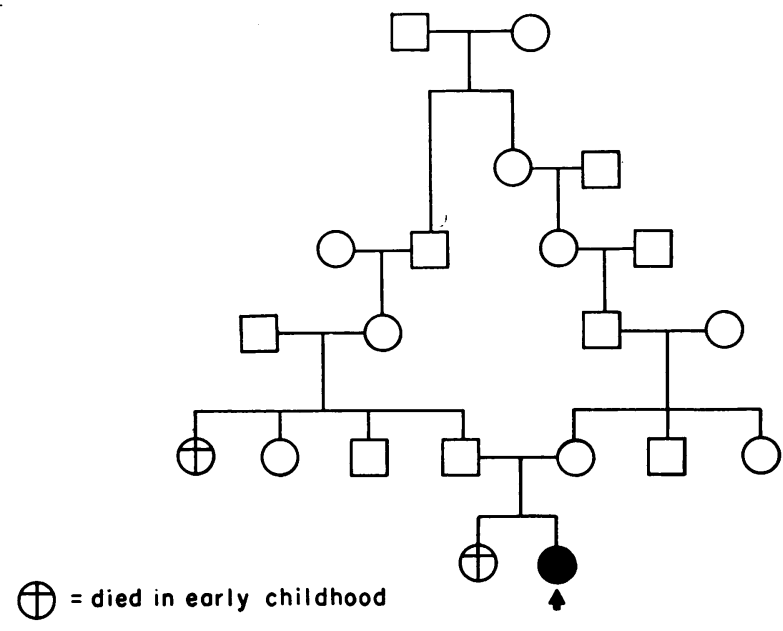

FIGURE 1 Family tree of patient E. G. The parents of the patient are second cousins once removed. The precise cause of death of the patient's sister is unclear.

(0.14-0.21 mmoles/liter) were above the normal range (0.07-0.12 mmoles/liter). Uric acid in blood (7.6-9.8 mg/ $100 \mathrm{ml}$ ) was also elevated.

Serum $\mathrm{CO}_{2}$ concentration remained below $20 \mathrm{mEq} /$ liter, despite therapy with $4.4 \mathrm{~g} /$ day of oral sodium bicarbonate. Values as low as 6 have been recorded. Serum sodium (137-141 $\mathrm{mEq} /$ liter), potassium $(4.1-4.9 \mathrm{mEq} / \mathrm{liter})$ and chloride (104-106 mEq/liter) appeared normal. Creatine phosphokinase in the serum (127 U) was slightly elevated (normal 6-50 U), as was serum aldolase (11 U; normal 3-8 U). Activities of glutamic-oxaloacetic transaminase and lactic dehydrogenase in her serum were normal.

Amino acid analysis of a single sample of urine by column chromatography demonstrated slightly increased excretion of alanine (566 vs. normal $12-500 \mu$ moles $/ 24 \mathrm{hr}$ ). Urinary ketones appeared elevated, by the nitroprusside test. Urine contained uric acid crystals; urate excretion was 8-20 mg/( $\mathrm{kg}$ body weight $\times$ day $)$. Urine $\mathrm{pH}$ was 5.0 . Urinalysis was otherwise unremarkable.

Electroencephalography demonstrated a nonlateralized mixture of slow waves abnormal even for this age.

Normal results were obtained on hematologic examination, and on measurements of blood levels of glucose, urea, creatinine, calcium, phosphorus, bilirubin, alkaline phosphatase, total protein, cholesterol, and triglycerides. Electrophoresis of serum proteins and plasma lipoproteins gave normal patterns. Roentgenographic examinations showed a normal bone age and mild demineralization.

Metabolic studies of fibroblasts. Materials: Sodium-[1$\left.{ }^{14} \mathrm{C}\right]$ pyruvate $(2.89 \mathrm{mCi} / \mathrm{mmole})$ and sodium- $\left[2-{ }^{14} \mathrm{C}\right]$ pyruvate $(3.44 \mathrm{mCi} / \mathrm{mmole})$ from $\mathrm{New}$ England Nuclear (Boston, Mass.) were stored as the dry powder at $-80^{\circ} \mathrm{C}$ under $\mathrm{N}_{2}$ in containers containing pyrogallol and $\mathrm{KOH}$. Palmitic acid- $\left[1-{ }^{14} \mathrm{C}\right](55.2 \mathrm{mCi} / \mathrm{mmole})$ from Amersham/ Searle Corp. (Arlington Heights, Ill.) was $98 \%$ radiopure by gas-liquid chromatography, and was used complexed to albumin in a ratio of 4 moles of fatty acid to 1 mole of protein. Citric acid-[1,5- $\left.{ }^{14} \mathrm{C}\right](9.10 \mathrm{mCi} / \mathrm{mmole})$, citric acid- $\left[6{ }^{-14} \mathrm{C}\right](5.14 \mathrm{mCi} / \mathrm{mmole})$, and glutamic acid-[U- $\left.{ }^{14} \mathrm{C}\right]$ (218 $\mathrm{mCi} / \mathrm{mmole})$, from New England Nuclear, were repurified by paper chromatography in $n$-butanol, acetic acid, water $=12: 3: 5$ before use. Sodium, D,L-isocitrate- $\left[5,6-{ }^{14} \mathrm{C}\right]$
(1.00 $\mathrm{mCi} / \mathrm{mmole}$ ) from $\mathrm{New}$ England Nuclear contained an equal mixture of all four possible stereoisomers and was used without further purification.

Thiamine pyrophosphate, NADP (yeast), and ADP were all A-grade from Calbiochem (San Diego, Calif.) Coenzyme A (grade I), NAD (grade III), cis-aconitic acid, oxaloacetic acid, D,L-isocitric acid, oxidized and reduced thioctic acids, and sodium pyruvate were from Sigma Chemical Co. (St. Louis, Mo.). Cysteine was from Nutritional Biochemical Corp. (Freehold, N. J.), nicotinamide from Eastman Organic Chemicals Div. (Rochester, N. Y.), and crystalline human albumin from Pentex Biochemical (Kankakee, Ill.). Lactic dehydrogenase (L-lactate: NAD oxidoreductase, E.C. 1.1.1.27) (18) from rabbit muscle (SA $360 \mu \mathrm{moles} /[\mathrm{mg}$ protein $\times \mathrm{min}]$ ) and phosphotransacetylase (Acety1-CoA : orthophosphate acetyltransferase, E.C.2.3.1.8) (19) from Clostridium cluyveri (SA $700 \mu \mathrm{moles} /[\mathrm{mg}$ protein $\times$ min] ) were from Boehringer Mannheim Corp. (New York); NADP-specific isocitric dehydrogenase (threo-Dsisocitrate: NADP oxidoreductase (decarboxylating), E.C. 1.1.1.42) (20) from pig heart $(2.5 \mu$ moles/[mg protein $X$ min]) was from Calbiochem. Other reagents were of analytical grade.

Fibroblast incubations. Skin fibroblasts were prepared and incubated with radioactive pyruvate, palmitate, and glutamate as described previously (21). For incubations with citric or isocitric acids, cells were treated with $0.1 \%$ trypsin for $40 \mathrm{~min}$ and then incubated in half isotonic buffer. Preliminary experiments indicated that oxidation of these substrates by fibroblasts was very slow unless cells were treated with detergent or hypotonic media, presumably because of slow passage of the tricarboxylic acids across the undamaged cell membrane. Control fibroblasts were from adults and children with other neurological diseases and from apparently normal foreskins.

Enzyme assays. Fibroblasts were disrupted by sonication (21) or, for measurement of citrate synthase (22) by

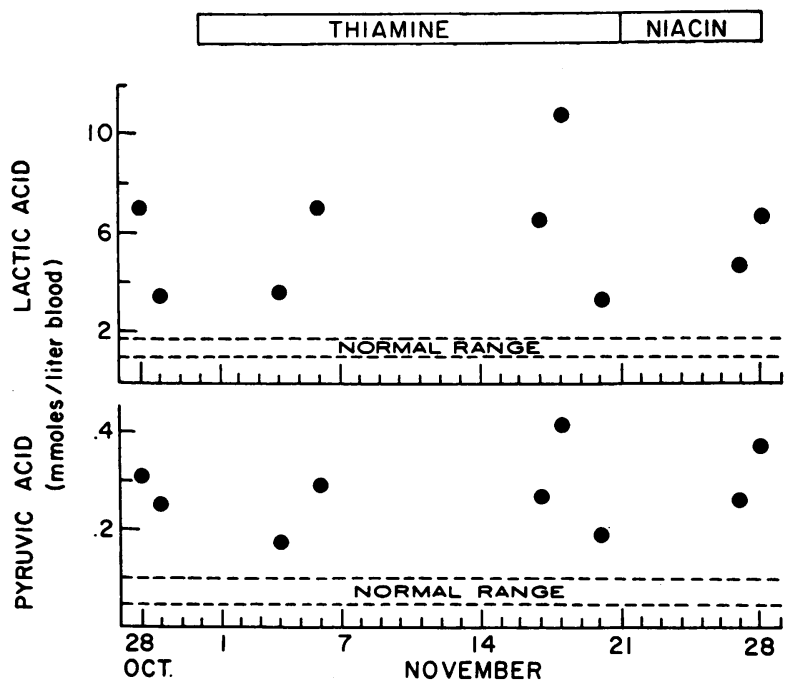

FIGURE 2 Levels of lactic and pyruvic acids in blood. Blood was obtained in the morning before feeding, as clcse to the basal state as was possible with this irritable child. Levels of lactic and pyruvic acids were determined by enzymatic methods in routine use in the NIH clinical laboratories. Dosages of vitamins are given in the text. 


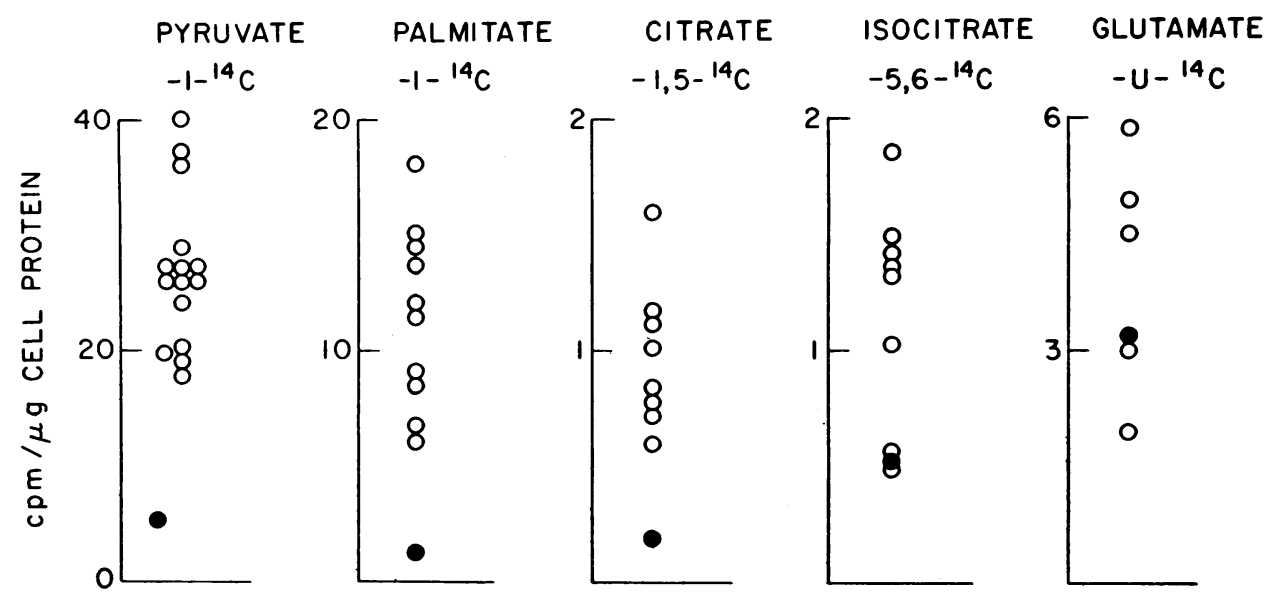

FigURE 3 Oxidation of various substrates by intact fibroblasts from patient E. G. (๑) and controls (O). Fibroblasts were incubated with various radioactive substrates and the evolved ${ }^{14} \mathrm{CO}_{2}$ measured, as described in detail in the text. Each point represents the mean of duplicate determinations on at least three cultures from each individual (patient or control).

lyophilization. Protein was measured by the modified biuret (23) or Lowry (24) techniques.

Pyruvate dehydrogenase complex (25). The activity of the pyruvate dehydrogenase complex was estimated by incubating, in a final volume of $0.25 \mathrm{ml}, 75-500 \mu \mathrm{g}$ of fibroblast protein; $20 \mu$ moles of potassium phosphate buffer, $\mathrm{pH}$ $7: 4 ; 0.8 \mu$ moles of $\mathrm{MgCl}_{2} ; 0.024 \mu$ moles of thiamine pyrophosphate; $0.03 \mu$ moles of NAD; $0.012 \mu$ moles of coenzyme A ; $0.8 \mu$ moles of cysteine; $4 \mu$ moles of nicotinamide; and $0.076 \mu \mathrm{Ci}$ of sodium- $\left[1-{ }^{14} \mathrm{C}\right]$ pyruvate. Meticulous attention to the details of sonication was necessary to obtain reproducible results in this assay. Incubations were in duplicate. The ${ }^{14} \mathrm{CO}_{2}$ was collected without acidification of the reaction mixture and counted as described previously (21). From 1 to $4 \%$ of the substrate was converted to ${ }^{14} \mathrm{CO}_{2}, 2-10$ times as much as in simultaneous incubations with sonicates inactivated by boiling under $\mathrm{N}_{2}$ or by addition of 4 vol of ethanol. In later experiments, $0.25 \mu$ moles of $\mathrm{Na}_{2} \mathrm{SO}_{3}$ was added to the incubation mixture to reduce the "blank" value for nonenzymatic oxidation. This nonenzymatic decarboxylation appeared due largely to the thiols. Incubation of pyruvate- $\left[1-{ }^{14} \mathrm{C}\right]$ with cysteine, coenzyme A, or dithiothreitol led to slight production of ${ }^{14} \mathrm{CO}_{2}$ even in the absence of protein. Addition of $\mathrm{Na}_{2} \mathrm{SO}_{3}, \mathrm{Na}-$ $\mathrm{HSO}_{3}$, or $\mathrm{FeSO}_{4}$ counteracted this effect, perhaps by removing thioperoxides.

Aconitate hydratase (Citrate (isocitrate) hydro-lyase, E.C. 4.2.1.3.) was measured by two techniques (26). In the first, $70-300 \mu \mathrm{g}$ of fibroblast protein, $0.4 \mu$ moles of $\mathrm{MgCl}_{2}, 0.07 \mu$ moles of NADP, $0.21 \mu$ moles of citric acid$\left[5,6{ }^{14} \mathrm{C}\right], 10 \mu$ moles of tris acetate buffer $(\mathrm{pH} 7.2)$, and $0.025 \mathrm{U}$ of commercial isocitric dehydrogenase were incubated, in duplicate, in a final volume of $0.13 \mathrm{ml}$, for $30 \mathrm{~min}$ at $37^{\circ} \mathrm{C}$. The evolved ${ }^{14} \mathrm{CO}_{2}$ was measured. Preliminary experiments indicated that excess isocitric dehydrogenase was present so that activity of this enzyme was not limiting oxidation. Production of ${ }^{14} \mathrm{CO}_{2}$ was negligible in the absence of fibroblast sonicates. In the second assay, 20-350 $\mu \mathrm{g}$ of fibroblast protein, $1 \mu$ mole of sodium isocitrate-[5,6$\left.{ }^{14} \mathrm{C}\right]$ and $20 \mu$ moles of potassium phosphate buffer $(\mathrm{pH}$ 7.4) were incubated in a final volume of $0.21 \mathrm{ml}$ for $30 \mathrm{~min}$. After addition of $0.2 \mathrm{ml}$ of $2 \%$ cis-aconitate in $0.5 \mathrm{~N} \mathrm{HCl}$, portions of $20 \mu \mathrm{l}$ from each extract were chromatographed on cellulose sheets (Eastman Chromagram sheets) in diethyl ether: formic acid, 7:1, saturated with water (22). The areas containing aconitic acid were located by examination under ultraviolet light, cut into scintillation vials and counted after addition of $15 \mathrm{ml}$ of toluene-methanol phosphor (21).

Isocitrate dehydrogenase activity was measured for both the NAD-linked (threo- $\mathrm{D}_{\mathrm{s}}$-Isocitrate: NAD oxidoreductase (decarboxylating) E.C. 1.1.1.41) and NADP-linked enzymes $(20,27)$. For the former, $50-320 \mu \mathrm{g}$ of fibroblast protein, $10 \mu$ moles of ADP, $0.11 \mu$ moles of NAD, and $0.018 \mu$ moles of isocitric acid- $\left[5,6-{ }^{14} \mathrm{C}\right]$ were incubated in duplicate in a total volume of $0.12 \mathrm{ml}$ for $30 \mathrm{~min}$ at $37^{\circ} \mathrm{C}$ and the ${ }^{14} \mathrm{CO}_{2}$ evolved counted. To measure NADP-linked activity, the NAD and ADP were replaced by $0.08 \mu$ moles of NADP, and 10-130 $\mu \mathrm{g}$ of fibroblast protein were added. Pyruvate decarboxylase (2-Oxoacid carboxy-lyase, E.C. 4.1.1.1.) and citrate synthase (Citrate oxaloacetate-lyase (CoA-acetylating), E.C. 4.1.3.7.) were measured as described previously $(21,22)$.

\section{RESULTS}

Studies of intact fibroblasts. For all incubations, conditions were adjusted so that the production of ${ }^{14} \mathrm{CO}_{2}$ was proportional to the number of cells added and to the length of the incubation. ${ }^{1}$ Fibroblasts from the patient oxidized pyruvic acid- $\left[1-{ }^{14} \mathrm{C}\right]$, palmitic acid- $\left[1-{ }^{14} \mathrm{C}\right]$, and citric acid- $\left[1,5-{ }^{14} \mathrm{C}\right]$ to ${ }^{14} \mathrm{CO}_{2}$ to less than one-third the extent of cells from controls (Fig. 3). Oxidation of pyruvic acid- $\left[2-{ }^{14} \mathrm{C}\right]$ was similarly low. Oxidation of isocitric acid- $\left[5,6-{ }^{14} \mathrm{C}\right]$ and glutamic acid-[U $\left.-{ }^{14} \mathrm{C}\right]$ was comparable with control cells.

Cell-free preparations. For each of the enzymes assayed, conditions were chosen so that activity was pro-

${ }^{1}$ Figures illustrating this and several other points have been submitted to the editors of the Journal. The authors would willingly send copies to interested readers. 
TABLE I

Cofactor Dependence of the Pyruvate Dehydrogenase Complex in Sonicated Fibroblasts

\begin{tabular}{ccr}
\hline Reaction mixture & \multicolumn{2}{c}{ Activity } \\
\hline & $\begin{array}{c}n \text { moles } / \\
\left(\mathrm{mg}^{-1} \times \text { min }^{-1}\right)\end{array}$ & $\%$ \\
Complete & 0.412 & 100 \\
$-\mathrm{Mg}$ & 0.310 & 75 \\
- TPP & 0.185 & 45 \\
- NAD & 0.246 & 60 \\
- Coenzyme A & 0.127 & 31 \\
- Cysteine & 0.370 & 90 \\
- Na $\mathrm{SO}_{3}$ & 0.468 & 114 \\
- Niacin & 0.398 & 96 \\
- All cofactors & 0.083 & 20 \\
\hline
\end{tabular}

Fibroblasts from a control subject were incubated as described in the text, except that specific cofactors were omitted as indicated.

portional to the amount of fibroblast protein added and to the length of the incubation, for preparations from the patient and from controls. ${ }^{1}$ Full activity of the pyruvate dehydrogenase complex depended on the presence of added cofactors (Table I). The extent of this dependence varied, even among preparations from the same cell line. Addition of either oxidized or reduced thioctic acid did not increase activity. Addition of lactic dehydrogenase or phosphotransacetylase did not increase activity (25), indicating that accumulation of NADH and acetyl-Coenzyme $\mathrm{A}$ was not limiting the reaction $(28,29)$.

Although the results with intact fibroblasts suggested that there might be a defect in the conversion of citrate to isocitrate in the patient's cells, the activity of aconitate hydratase in her sonicated cells appeared normal, by two different assays (Table II). The Michaelis-Menten constants for the interaction of citric and with aconitate

TABLE II

Activity of Several Enzymes in Disrupted Fibroblasts from Patient E. G. and Controls

\begin{tabular}{lccc}
\hline \multicolumn{1}{c}{ Enzyme } & Patient E. G. & Controls \\
\hline & \multicolumn{2}{c}{ nmoles $/(m g$ protein $\times$ min $)$} \\
Citrate synthase & $15.3 \pm 0.26$ & $24.9 \pm 3.1(20.3-31.8)$ \\
Aconitate hydratase & & $0.41 \pm 0.06$ & $0.51 \pm 0.04(0.38-0.61)$ \\
$\quad \begin{array}{l}\text { Citrate to isocitrate } \\
\text { Isocitrate to aconitate }\end{array}$ & $0.48 \pm 0.06$ & $0.67 \pm 0.10(0.41-0.91)$ \\
Isocitric dehydrogenase & & & \\
$\quad$ NADP linked & $1.56 \pm 0.25$ & $1.77 \pm 0.33(1.13-2.99)$ \\
NAD linked & $0.119 \pm 0.030$ & $0.150 \pm 0.027(0.093-0.248)$ \\
\hline
\end{tabular}

Activities were determined as described in detail in the text and in reference 22. Values are the mean of duplicate determinations on at least three cultures each from the patient and from at least four control subjects. The range of values for controls are also shown. hydratase ${ }^{1}$ and the activities of both the NAD-linked and NADP-linked isocitrate dehydrogenases in preparations from the patient's cells were also normal (Table II) while the activity of citrate synthase in her cells was about three-fourths of that of the lowest of four controls (22).

The activity of the pyruvate dehydrogenase complex, however, was significantly lower in the patient's sonicated fibroblasts than in preparations from control cells (Table III). The defect was as marked as that in pyruvate oxidation in her intact cells. Activity in sonicated fibroblasts from the mother was at the lower limit of the range for controls; cells from the father were not available for study. Mixing experiments did not demonstrate the presence of a soluble inhibitor of the pyruvate dehydrogenase complex in the patient's cells (Table IV). Addition of excess NAD, ${ }^{1}$ coenzyme $A,{ }^{1}$ reduced or oxidized thioctic acid, ${ }^{1}$ or of excess pyruvate did not significantly increase activity in the patient's sonicated cells. Attempts to measure the Michaelis-Menten constants for Coenzyme A and NAD in sonicated fibroblasts were unsuccessful.

Conversion of pyruvate- $\left[1-{ }^{14} \mathrm{C}\right]$ to ${ }^{14} \mathrm{CO}_{2}$ with ferricyanide as an electron acceptor was only slightly less with sonicated fibroblasts from the patient (40 nmoles/ $[\mathrm{mg}$ protein $\times \min ]$ ) than with preparations from controls (41-115 nmoles/[mg protein $\times \min ]$ ) at $30^{\circ} \mathrm{C}$. Extensive studies have demonstrated that ferricyanide reacts with the hydroxyethylthiamine formed as an intermediate by the first, thiamine-dependent enzyme of the

\section{TABLE III}

Activity of the Pyruvate Dehydrogenase Complex in Sonicated Fibroblasts from Patient E. G., Her Mother, and Controls

\begin{tabular}{cc}
\hline Subject & Activity \\
\hline & nmoles $/($ mg protein $\times$ min $)$ \\
Controls : & $0.392 \pm 0.032(9)$ \\
W. G. & $0.556 \pm 0.208(3)$ \\
M. F. V. & $0.494 \pm 0.072(3)$ \\
M. V. & $0.444 \pm 0.058(3)$ \\
A. M. & $0.442 \pm 0.041(4)$ \\
J. G. & $0.364 \pm 0.088(3)$ \\
A. I. & $0.330 \pm 0.067(3)$ \\
F. B. & $0.316 \pm 0.080(3)$ \\
J. W. & $0.291 \pm 0.051(4)$ \\
L. H. & $0.288 \pm 0.098(3)$ \\
Mother (H. G.) & $0.229 \pm 0.062(5)$ \\
Patient (E. G.) & $0.059 \pm 0.014(14)$
\end{tabular}

The activity of the pyruvate dehydrogenase complex was assayed in sonicated fibroblasts as described in detail in the text. Values represent means, \pm SEM. The figures in parentheses represent the number of cultures examined for each individual (patient or control), or, for the total control group, the number of individuals studied. 
TABLE IV

Activity of the Pyruvate Dehydrogenase Complex in Mixtures of Sonicated Fibroblasts from Patient E. G. and Controls

\begin{tabular}{rrrccc}
\hline \multicolumn{2}{c}{ Sonicate added } & & \multicolumn{3}{c}{ Activity } \\
\cline { 5 - 6 } Patient & Control & & Observed & Calculated & Obs./Calc. \\
\hline \multicolumn{2}{c}{$\mu g$ protein } & & $c m p$ & $c p m$ & $\%$ \\
271 & 0 & & 1462 & - & - \\
203 & 189 & & 3865 & 3934 & $98 \%$ \\
136 & 378 & & 5783 & 6406 & $90 \%$ \\
78 & 568 & & 9945 & 8878 & $112 \%$ \\
0 & 756 & & 11351 & - & - \\
\hline
\end{tabular}

Activity was determined as described in the text, in mixtures of sonicated fibroblasts from patient E. G. and from a control. The calculated values represent the sum of the activities expected from the amounts of patient or control sonicate added, assuming that mixing did not change the specific activities of those preparations. The results of one of three similar experiments are shown.

pyruvate dehydrogenase complex (30). The results of the assay with ferricyanide therefore indicate that the activity of this enzyme and its interaction with pyruvate, thiamine pyrophosphate, and $\mathrm{Mg}^{++}$were all normal (21, 25). The defect in this patient's cells therefore appears to affect one of the latter two of the three enzymes in the pyruvate dehydrogenase complex.

\section{DISCUSSION}

In this patient, there appears to be a partial defect in the oxidation of metabolites through the tricarboxylic acid cycle. Conversion of radioactive pyruvate, palmitate, and citrate to ${ }^{14} \mathrm{CO}_{2}$ was low in her cultured fibroblasts. The accumulation of excess pyruvate and citrate in her blood suggested that metabolism of these compounds was defective in tissues of the intact patient. The lactic acidosis was consistent with excess glycolysis due to inadequate production of ATP by oxidative metabolism (31).

The activity of the pyruvate dehydrogenase complex was low in cell-free preparations of the patient's fibroblasts, but we are unable to explain the low oxidation of palmitate and citrate by the patient's intact cells on the basis of that defect alone. Complex interactions do occur between the oxidation of pyruvate and of citrate (32-36). Furthermore, the defect in this patient appears to affect one of the two latter enzymes of the pyruvate dehydrogenase complex, the last enzyme of which may be identical with the last enzyme of the $\alpha$-ketoglutarate dehydrogenase complex $(37,38)$. Normal conversion of glutamate- $\left[\mathrm{U}_{-}{ }^{14} \mathrm{C}\right]$ to ${ }^{14} \mathrm{CO}_{2}$ by her cells does not rule out a defect in the $\alpha$-ketoglutarate dehydrogenase complex, since glutamate is metabolized by a variety of mechanisms. Defective oxidation of $\alpha$-ketoglutarate could conceivably lead to accumulation of citrate (with relatively little increase in isocitrate). The resulting increased intracellular pools of citrate would impair oxidation of added radioactive citrate by dilution of the isotope. We have been unable to measure directly in the patient's cells the activity of the $\alpha$-ketoglutarate dehydrogenase complex, the levels of glycolytic and oxidative intermediates, or the relevant regulatory parameters (39). More detailed studies of the human pyruvate and $\alpha$-ketoglutarate dehydrogenase complexes and of carbohydrate metabolism in cultured human fibroblasts may clarify some of these problems.

The mechanism of inheritance of this defect has not been precisely defined, but the consanguinity and the low activity of pyruvate dehydrogenase in the mother's sonicated cells suggest recessive inheritance.

This patient differs both biochemically and clinically from the three children we have described with defects in the first enzyme of the pyruvate dehydrogenase complex $(21,40)$. Intact fibroblasts from the patient described in this report oxidized palmitate and citrate at low rates, while with ferricyanide as electron acceptor her sonicated fibroblasts oxidized pyruvate at rates similar to controls. Intact fibroblasts from the other three patients oxidized palmitate and citrate normally, but their sonicated cells were defective in the ferricyanide-linked oxidation of pyruvate. The patient described here had severe, generalized neurologic disease. The only prominent and consistent finding in the other three was intermittent ataxia $(21,40)$.

Profound neurologic disease is not surprising in a patient with a major oxidative defect. Even brief interference with oxidative metabolism by anoxia or poisons can lead to brain damage. The major normal substrate for oxidation in the nervous system is glucose (41). Different enzymatic defects in glucose oxidation or in the supply of glucose by gluconeogenesis might be expected to lead to clinical disorders which differed in detail but which led to patients having the combination of neurologic disease and lactic acidosis. Defects in gluconeogenesis have been described in several such patients $(7,9,11,13,14)$, including two $(11,14)$ with defective hexosediphosphatase (D-Fructose-1,6-diphosphate-1-phosphohydrolase, E.C. 3.1.3.11) and two others $(7,9)$ with defects in pyruvate carboxylase (Pyruvate: carbon-dioxide ligase (ADP), E.C. 6.4.1.1.). Several workers have postulated defects in oxidative metabolism in other such patients, on the basis of accumulation of $\alpha$-ketoglutaric acid $(2,5,6,10)$, accumulation of glyoxylic acid (5), increased production of lactic acid by exercising muscle (3) and by red blood cells (4), or response to therapy with lipoic acid $(5,10)$. Studies in vitro of fibroblasts from the patient described in this 
report demonstrated an oxidative defect. Patients with congenital lactic acidosis do appear to constitute a biochemically heterogeneous group.

The studies described above indicate that a partial defect affecting the tricarboxylic acid cycle can be compatible with extrauterine life. Even for the activities of very critical enzymes, it appears reasonable to expect a range of values compatible with normal life, a range compatible with life but not with normal function, and a range incompatible with extrauterine life. Demonstrations of biochemical heterogeneity in human populations are increasingly common (42). The existence of mutations which cause defects of each of these three types would not be surprising.

\section{ACKNOWLEDGMENTS}

We thank Doctors Martha Vaughan, Jay Seegmiller, and George Popjak for advice and support and Mrs. Kay Bradley, Mrs. Sandra Harris, and Mr. Rodger Johnson for skilled technical assistance.

This work was supported in part by grants HD 04612, HD 00345, and HD 05615 from the National Institute of Child Health and Human Development.

\section{REFERENCES}

1. Hartman, A. F., H. J. Wohltman, M. L. Puckerson, and M. E. Wesley. 1962. Lactate metabolism-studies of a child with a serious congenital deviation. J. Pediat. $61: 165$

2. Israels, S., J. C. Haworth, B. Gourley, and J. D. Ford. 1964. Chronic acidosis due to an error in lactate and pyruvate metabolism. Pediatrics. 34: 346.

3. Erickson, R. J. 1965. Familial infantile lactic acidosis. J. Pediat. 66: 1004 .

4. Worsley, H. E., R. W. Brookfield, J. S. Elwood, R. L. Noble, and W. H. Taylor. 1965. Lactic acidosis with necrotizing encephalopathy in two sibs. Arch. Dis. Childhood. 40: 492.

5. Clayton, B. E., R. H. Dobbs, and A. D. Patrick. 1967. Leigh's subacute necrotizing encephalopathy: clinical and biochemical study, with special reference to therapy with lipoate. Arch. Dis. Childhood. 42: 467.

6. Haworth, J. C., J. D. Ford, and M. K. Younoszai. 1967. Familial chronic acidosis due to an error in lactate and pyruvate metabolism. Can. Med. Ass. J. 97: 773.

7. Hommes, F. A., H. A. Polman, and J. D. Reerink. 1968. Leigh's encephalomyopathy: an inborn error of gluconeogenesis. Arch. Dis. Childhood. 43: 423.

8. Scharer, K., A. Marty, and J. Muhlenthaler. 1968. Chronic congenital lactic acidosis. Helv. Paediat. Acta. 23: 107 .

9. Tada, K., T. Yoshida, T. Konno, Y. Wada, Y. Yokoyama, and T. Arakawa. 1969. Hyperalanemia with pyruvicemia. Tohoku J. Exp. Med. 97 : 99.

10. Greene, H. L., W. K. Schubert, and G. Hug. 1970. Chronic lactic acidosis of infancy. J. Pediat. 76: 853.

11. Pagliara, A. S., I. E. Karl, J. Keating, B. Brown, and D. M. Kipnis. 1971. Hepatic fructose-1,6-diphosphatase deficiency: a cause of lactic acidosis and hypoglycaemia in infancy. Clin. Res. 19: 481.

12. Lie, S. O., A. C. Loken, J. H. Stromme, and O. Aagenaes. 1971. Fatal congenital lactic acidosis in two siblings. I. Clinical and pathological findings. Acta Paediat. Scand. 60: 129.

13. Skrede, S., J. H. Stromme, O. Stokke, S. O. Lie, and L. Eldjarn. 1971. Fatal congenital lactic acidosis in two siblings. II. Biochemical studies in vivo and in vitro. Acta Paediatr. Scand. 60: 138.

14. Baker, L., and A. I. Winegrad. 1970. Fasting hypoglycemia and metabolic acidosis associated with a deficiency of hepatic fructose-1,6-diphosphatase activitya new syndrome. Clin. Res. 18: 281 .

15. Brunette, M. G., B. Hazel, C. R. Scriver, F. Mohyuddin, and L. Oallaire. 1970. Thiamine dependent neonatal lactic acidosis with hyperalaninemia. Clin. Res. 18: 286.

16. Blass, J. P., J. D. Schulman, and D. S. Young. 1970. A defect in the oxidation of citric acid in a patient with congenital lactic acidosis. Clin. Res. 18: 451.

17. Pellet, M. V., C. Seigner, and H. Cohen. 1969. Fluorimetric titration of citric acid. Use in autoanalysis. Pathol. Biol. 17 : 909.

18. Kornberg, A. 1955. Lactic dehydrogenase of muscle. Methods Enzymol. 1 : 441.

19. Stadtman, E. R. 1955. Phosphotransacetylase from $\mathrm{Cl}$. Kluyveri. Methods Enzymol. 1: 596.

20. Cleland, W. W., V. W. Thompson, and R. E. Barden. 1969. Isocitrate dehydrogenase (TPN-Specific) from pig heart. Methods Enzymol. 13: 30.

21. Blass, J. P., J. Avigan, and B. W. Uhlendorf. 1970. A defect in pyruvate decarboxylase in a child with an intermittent movement disorder. J. Clin. Invest. 49: 423.

22. Schulman, J. D., and J. P. Blass. 1971. Measurement of citrate synthase activity in human fibroblasts. Clin. Chim. Acta. 33: 467.

23. Zamenhof, S. 1957. Preparation and assay of deoxyribonucleic acid from animal tissue. Methods Enzymol. 3: 702 .

24. Layne, E. 1957. Protein estimation with the Folin-Ciocalteu reagent. Methods Enzymol. 3: 448.

25. Reed, L. J., and C. R. Wilms. 1966. Purification and Resolution of the pyruvate dehydrogenase complex ( $E$. Coli). Methods Enzymol. 9: 247

26. Fansler, B., and J. M. Lowenstein. 1969. Aconitase from pig heart. Methods Enzymol. 13: 26.

27. Plaut, G. W. E. 1969. Isocitrate dehydrogenase (DPN specific) from bovine heart. Methods Enzymol. 13: 34.

28. Bremer, J. 1969. Pyruvate dehydrogenase, substrate specificity and product inhibition. Eur. J. Biochem. 8: 535.

29. Wieland, O., B. von Jagow-Westerman, and B. Stukowski. 1969. Kinetic and regulatory properties of heart muscle pyruvate dehydrogenase. Z. Physiol. Chem. (Hoppe-Seyler's). 350: 329.

30. Krampitz, L. O. 1969. Catalytic functions of thiamine diphosphate. Annu. Rev. Biochem. 38: 213.

31. Oliva, P. B. 1970. Lactic acidosis. Amer. J. Med. 48: 209.

32. Ruffo, A., A. Adinolfi, G. Budillon, and G. Capobianco. 1962. Control of the citric acid cycle by glyoxalate. II. Mechanism of the inhibition of respiration in liver and kidney particles. Biochem. J. 85: 593.

33. Buckle, R. M. 1963. The glyoxylic acid content of human blood and its relationship to thiamine deficiency. Clin. Sci. (London). 25 : 207.

34. Liang, C. C. 1962. Studies on experimental thiamine deficiency, II. Tissue breakdown and glyoxylic acid formation. Biochem. J. 83: 101. 
35. Clark, J. B., and W. J. Nicklas. 1970. Metabolism of rat brain mitochondria. Preparation and characterization. J. Biol. Chem. 245: 4724.

36. Martin, D. B., and C. K. Silbert. 1969. Control of pyruvate dehydrogenase in rat liver mitochondria by citrate. Proceedings of the 6th Congress of the International Diabetes Federation. J. Ostman, editor. Excerpta Medica Foundation, Publishers, Amsterdam. 350.

37. Hayakawa, T., T. Kanzaki, T. Kitamura, Y. Fukuyoshi, Y. Sakurai, K. Koike, T. Suematsu, and M. Koike. 1969. Mammalian $\alpha$-keto dehydrogenase complexes. V. Resolution and reconstitution studies of the pig heart pyruvate dehydrogenase complex. J. Biol. Chem. 244: 3660 .
38. Sakurai, Y. 1970. Multiple forms of pig heart lipoamide dehydrogenase. Seikagaku. $42: 726$.

39. Shen, L. C., and D. E. Atkinson. 1970. Regulation of pyruvate dehydrogenase complex from Escherichia coliinteractions of adenylate energy charge and other regulatory parameters. J. Biol. Chem. $245: 5974$.

40. Blass, J. P., D. Lonsdale, B. W. Uhlendorf, and E. Hom. 1971. Intermittent ataxia with pyruvate decarboxylase deficiency. Lancet. I: 1302.

41. Bradford, H. F. 1968. Carbohydrate and energy metabolism. In Applied Neurochemistry. A. N. Davison, editor. Blackwell' Scientific Publications Ltd., Oxford. 222.

42. Harris, H. 1969. Enzyme and protein polymorphism in human populations. Brit. Med. Bull. 25: 5 . 